\title{
THEORETICAL CONCEPT OF LEARNING PROCESS IN FOLK HIGH SCHOOL
}

\author{
Tautas skolu mācību procesa teorētiskais koncepts
}

\author{
Ludmila Babajeva \\ University of Latvia, Latvia \\ E-mail: ludmila.babajeva@lu.1v
}

\begin{abstract}
Folk high schools during last 160 years have been known for being unique nonformal education institutions with their own philosophical conception established by Danish philosopher N.F.S. Grundtvig (1783-1872). Founded as national consciousness and Danish culture supportive institutions, folk high schools in short time became centres of democracy. The main ideas of these conception - ,,living word”, ,, enlightenment”, ,,enliving”, ,, school for life”, ,personal development" - have made these institutions as providers of personal enlightenment, development and self-realization, where students enlived their transformations through dimensions of body, feelings and mind.
\end{abstract}

Keywords: adult learning, Denmark, folk high school, Grundtvig.

\section{Introduction}

Folk high school as a kind of non-formal education is not meant only for giving formal lectures and knowledge (Andresen, 1981). It is a specific education establishment where the learning process takes place on the basis of volunteering, knowledge, skills and competences are not evaluated by mark and no definite demands for entering are put forward for candidates. The only impediment could be age restriction that is usually from 18 years old that was Gruntvig's idea from the very beginning and that is followed by folk high schools nowadays in Denmark.

Folk high school in modern Danish education system relates to non-formal education as a separate education establishment with its unique realized education. With regard to non-formal education in Denmark, 4 types of establishments altogether belong to it that realize this education: University extension services, day folk high schools, folk high schools and study associations.

Folk high school or in Dannish folkehojskoler is people's high school. It is not a folk school which means a public school in Denmark but definitely a folk high school. These schools differ with their old traditions that have survived though centuries during more than 160 years and their no-mark and no-diploma system.

Education of this kind strive to respond to personality's interests, motivation to study, recognize oneself and one's potential as well as to perfect oneself (Bose, 1960; Davis, 1971). Learning environment is characterized by close and friendly relationship among teachers, students and staff who spend 4 months together in average in one educational and cultural establishment.

In these institutions the focus is put on social and cultural issues. Students' growth is not so concentrated on knowledge acquisition but on broader perfection development of feelings and emotions as well as giving personal meaning to one's action. 
Learning process is directed to finding answers to questions that relate to students, their life, relationship and plans for future. These schools are annually attended by approximately $10 \%$ of Dannish population in the age of 20-30 years old (Davies, 1931).

Study content is not regulated by government - schools are practically completely free in choice of courses and subjects. The only regulation that exists nowadays is the Law of Free Boarding Schools that determines the known borders in school activity aims but it does not contradict to already performed actions.

\section{Overview of historical aspect of folk high school activity}

Nikolai Frederik Severin Grundtvig (1783-1872) - a philosopher, poet, prose-writer, clergymen and popular educator who is considered to be the founder of the theory of great folk high school education that is still so unique that it exists more than 160 years. Grundtvig came from the religious family as well as travelled to England (1829-1830), for instance, to popular Trinity College in Cambridge that left a considerable impression on his education ideas for people. He took ideas from German and Danish romanticism, Rousseau and Penstalozzi works as well as the Northern mythology.

As the author of many works, he is known by means of the following publications: „Mythodology”, „Conversations”, „The Masked Balli n Denmark”, „Scandinavian Mythology” and others that served as inspiration source for folk high school adherents in the whole world.

It must be pointed out that Grundtvig's ideas were not accepted at once, in the period from 1825 till 1853 church prohibited his works considering them to be too free to interpret ideas of church and christianity. (Campbell, 1928).

During the subjection of Denmark to German ideology Grundtvig, noticing that Dannish language and culture were disappearing, decided that there had to be a place in the folk high school where the national identity could be strengthened. As a result, the following appeared in folk high school education aims: awakening of folk spirit, education for everyone in the mother tongue language, Dannish history and culture etc. despite the fact that education programmes of the 19th century were broad enough, however, the national consciousness was one of the significant components.

The first folk high school was established in 1844 in Rodding as one of the basis of national identity rise and barrier for clash of Dannish and German cultures. (Davies, 1931; Davis, 1971). Gruntvig wanted to found first folk high school at Soro as the formal education establishment that at first was supported by government. Nevertheless, with the death of King Christina VIII, all the project was stopped and Gruntvig had to realize his ideas in a non-formal sector.

Grundtvig postulated the principles of folk high school in the following phrase: „Frit at taenke, tro og tale” - „Freedom of Thought, Religion, and Speech” (Rordam, 1965). As the main shool aim, strengthening of cultural consciousness and intellectual growth were put forward together with awakening and growth of personality. (Davis, 1971). 
Schools were founded more as enlightenment for life but not for professional education. Enlightenment meant something more for Grundtvig than pure knowledge, it was spiritual enlightment, acquisition of contents by means of emotions and feelings. Grundtvig wanted to give knowledge to ordinary people in order to make them the best citizens who can adjust to the changing social obstacles.

The folk high school movement has greatly contributed to the economic and spiritual development of Denmark - and as a result to the formation of democratic society (Rordam, 1965; Davies, 1931; Davis, 1971).

Students who had finished the course were well prepared in order to return to their houses where they successfully continued their work. These graduates realized themselved well in any work as they gained the competences of collaboration, cooperation and respect. It was heard that, for example, students were efficient nurses, however, these courses were not taught in folk high school because they had developped aspects of human and humanist attitudes. (Rordam, 1965). Already in 19th century an international programme appeared in folk high schools where students from other countries could acquire courses.

With regard to folk high school movement, not only Grundtvig has to be identified as the concept founder but also Christen Kold (1816-1870) who had elaborated his ideas that updated this school activity and he himself, as distinguished from Grundtvig, was a successfully practising teacher in Ryslinge folk high school that was founded in 1851 .

As distinct from Grundtvig who considered that history and poetics had to be interpreted in the way they were, Kold attempted to convert them to everyday moralizing and the source of discussion. Moreover, he was the first who started realizing the course for girls practically (that corresponds to Grundtvig's idea about education for everyone - both for boys and girls).

Both Kold and Grundtvig attempted to provoke feelings in their students. Kold considered that „heart and spirit” have to be awakened and only then it is possible to teach (that is close to Grundtvig's ,enliving” concept). Added to this, both authors emphasized homelike, trustful and close relations of school and students. (Davis, 1971)

The number of folk high schools has been increased with years and has reached the number of 80 schools till today according to the data of the Association of Folk High Schools in Denmark. Life and education conditions have been considerably improved and have become more comfortable already in the 20th century (Bertrup, 1936), and at the moment their everyday life has been updated by computerization that enables students to be easier oriented in school everyday life and to use electronic devices for completing homework. Bertrup considered that folk high school aims had stayed the same but in the learning process of school in the 20th century the bigger emphasis is put on discussions and students' work with books. Considering the 21 st century, it should be noted that students really learn more with illustrative aids - e.g. different posters, make notes, gather copied materials and prepare presentations in connection with their project. Thus, it can be 
seen that happening modernizations in formal education have touched upon also folk high schools. Nevertheless, the financial opportunities nowadays enable students to hike, to visit museums, the nearest schools, churches, to go to the theatre etc. in such a way upgrading informal education opportunities. Nowadays courses are less oriented to rural life than it was at the beginning of school activity (Prial, 1980).

\section{Folk high school as a unique education institution}

Columbia Electronic Encyclopedia gives a definition that an idea of folk high school is ,to stimulate the intellectual life of young adults (generally from 18 to 25 years old) of rural Denmark, to foster patriotism and strengthen religious conviction, and to provide agricultural and vocational training".

With relation to this definition, it should be clarified that Grundtvig never determined age restrictions noting only that the desirable age would be 18 years old when spirit was ready to think over life questions (in this respect Kold could not agree with him considering that this age was too late but however later accepted that Gruntvig was right). Grundtvig emphasized the period of time starting from 18 years old as he considered that only then a student was ready to perform a „spiritual creation", till this time these processes are not completed enough (Davies, 1931; Campbell, 1928).

Moreover, in this definition it was said about patriotism and strengthening of religious conviction that is partly true. It is due to the fact that, of course, the aim was to strengthen the national spirit by means of teaching history and Dannish language (Prial, 1980). Nevertheless, Grundtvig has never emphasized religious education, vice versa, he said: ,, at the beginning a human, after than a Christian”. Also nowadays in folk high schools there are no subjects in connection with religion but there are some distinct schools that are based on ideas from Bible but only several. Nevertheless, Grundtvig borrowed some good ideas from christianity and romanticism and pointed out that a human is a value because God is realized in him. (Rordam, 1965)

Grundtvig saw a person as a creation of God and a value as such and thus considered that it is not necessary to transform oneself and follow the ideal of church. Neverthelsess, it should be understood that Grundtvig acknowledged various christianity ideals but not always agreed to the way how church declared and obtruded on free people. (Bertrup, 1936; Davies, 1931).

Moreover, Grundvig, afterwards Campbell (1928), Davies (1931) and Rordam (1965) by their thoughts put the bigger emphasis on cultural subjects but not on vocational ones as there was a place for them in folk high schools that were put against ideas of folk high schools and did not give spiritual freedom and vivid discovery.

Davis (1971) having considered Dannish folk high schools as the model of humanistic education talks about these institutions as about ,school for human beings" in which specific conditions are created, where everyone can realize 
oneself in a desirable way. He mentions 7 features that, according to him, characterize these institutions in the best way:

1. no- examinations or diplomas system

2. free entering

3. freedom of teacher's qualification

4. emphasizing of social interaction

5. a student as a center of learning experience

6. volume of creative study subjects

7. broad range of subjects

Every student composes the learning plan independently according to own desires and opportunities - 3-4 months courses are offered that consist of compulsory, optional and free subjects. Moreover, in many schools nowadays students are divided into groups, for example, an international course, a musical course, a sewing course - these students in informal setting are together and share similar ideas (Bose, 1960).

The previous teachers' education, as it was mentioned before, is not an important factor in order to become a teacher in a folk high school - these demands were not established before according to legislation. Usually a folk high school director can determine what a teacher should be like as well as other teachers. Nevertheless, a director is approved by Ministry of Education (Rordam, 1965; Davis, 1971).

An essential difference of this kind of schools from others is the emphasis on social interaction when a director, teachers and students make one solid school core by sharing meals, school space, together participating in excursions and freely expressing their ideas to each other. In this school any questions - both serious and not so - are solved in a friendly and supporting setting. (Rordam, 1965).

Rordam and Davies have separated 4 main aspects that enabled to distinguish folk high school among other education institutions:

- it has to be a boarding school;

- it has to be at least 5-months course or two 3-months course;

- students have to come from all social classes and have different previous experience;

- study contents has to be based on cultural and social problems.

Every teacher has to follow 3 main demands: 1) availability for students also on Sundays, 2) at least 2 evenings are to be devoted to private talks with students and 3) always being open for previous students in any question. (Davis, 1971)

Teacher in folk high school has really many duties that has to be remembered before settling up for a job in this institution. This work can take the most part of time simultaneously not receiving a high salary. According to Rordam (1965) data, in ordinary day there were 20-25 hours per week from which 6-12 had to be devoted to lectures. According to Davis (1971) data teacher's workload can reach even 720 hours per year. In order to understand a teacher's daily routine easier, there is an illustrative example from the day routine of folk high school:

8:00 - morning assembly (singing); 
8:00-12:00 - lectures (basic subjects);

12:00-12:30 - dinner;

12:30-13:00 - duty time;

13:00-16:00 - optional subjects;

16:00-18:00 - clearning duty;

18:00-24:00 - free time.

Folk high school as an non-formal education institution is a unique and persistent unit with only its characteristic values. These establishments are not meant as rehabilitation ot psychological institutions but as self-realization, owners of democracy and socially-cultural values. Although, if it has been talked about non-formal education functions, in this context a word 'upgrading' according to the author's opinion, can be used judging by a person's life position and aim. (Davis, 1971; Andresen, 1981)

\section{Philosophical concept of folk high school education}

There are five different traditions of enlightenment: Christian enlightenment, civic enlightenment, popular-national enlightenment, workers' enlightenment, and personal enlightenment. In the opinion of Korsgaard (2000), it is personal enlightenment that is becoming increasingly important during the last 25 years. This tradition embodies concepts like personal growth and personal development.

According to the views postulated by Grundtvig, he saw personal enlightenment as 'as a search for light' (Korsgaard, 2000). In a sense enlightenment was also associated with God, appearing in the process of education as the embodiment of the highest cultural value. It may have been due to this reason why Gruntvig declared around 1810 that '...peoples' calamity and misery was due to their having turned their backs upon God and forsaken the true Christian faith; and that if they did not return to God, there would soon be an end to Denmark's history', meaning by this that not God alone been forsaken but humanity too (Bertrup, 1936).

Grundtvig believed in the power of God and never stopped worshipping it. In studying the philosophic beliefs of Grundtvig, I would like to concur with the opinion expressed by Bertrup (1936) that the principles of Christianity were adopted and used as the primary basis for the ideas of democracy. Grundtvig believed that every human being had a God inside him; that talents, abilities, and good qualities may be found in every man to develop and to add to in the process of education. Thus in his belief there appears the trust that all people are equal and everyone should be given a chance to learn and to enlighten themselves.

The human being as the highest value is best described using these words by Grundtvig: '...no, he is an unparalleled, marvellous creature, in whom divine forces shall manifest themselves, develop, and gain clarity through thousands of generations.." (Rordam, 1965; Davis, 1971).

Grundtvig believed in humanity, in what was good in a man; he also believed that education had to be delivered with a view to life and for the benefit of 
all men (despite the fact that the education of farmers was initially supported mainly by folk high schools. (Campbell, 1928).

The first principle that Grundtvig spoke of was 'awakening', which meant revival and stimulation of the life, an act, activity locked up in each person from his or her birth and is only waiting to come out. Awakening was closely related to the concept of living word - a teaching based on the live dialogue not on book-reading and restating their content, on the fresh exchange of ideas.

Grundtvig is known for his opposition against the "dead school"-he used this name to call schools existing in the $19^{\text {th }}$ century - and he wanted to replace them with a school for life, believing that the school had to prepare a pupil for life and work rather than for reading texts from his or her heart. Grundtvig postulated: 'Dead is all knowledge, which does not find response in the life of the reader.' (Davis, 1971).

Folk high school was synonymous with the second principle of "school for life'; this was how Grundtvig understood the possibility for students to learn to use their freedom also outside school walls and to develop a sense of belonging to a culture an important kernel of which is the awareness of oneself as part of the culture. (Davies, 1931). Davies thinks this sort of education may be described as '... movement which seeks to allow man to fulfil his potential, to allow him to become himself, Man".

There are two directions in which the school for life is viewed - in the light of man becoming an individual and in the light of man becoming a social being. He saw the entire life as a process of self-improvement evolving in two directions -the national one and the individual one (Campbell, 1928) or the social one and the individual one (Bertrup, 1936). The turning of man into an individual was seen as related to the discovery and fulfilment of one's potential, self-knowledge acquired from the aspects of inner and external activity. And, in turn, in preparing a person for life in a society the people's school assists the person in learning cultural values of the present and of the past, accepting responsibility for the current situation and his or her activity. (Davies, 1931).

And the third principle was incorporated in Grundtvig's beliefs about the "living word" as being opposed to the "dead school"; he expresses this thought in the following words: ,dead are letters, even if they be written with the fingers of angels, and dead is all knowledge which does not find response in the life of the reader.'

The living word was regarded as a way in which the spirit expresses itself; in this sense, the union of the souls of teachers and the students and the sharing of experience could only have happened through the use of the living word. (Davies, 1931). Grundtvig himself puts his idea this way: 'The spoken word is a spiritual body...the wonderful instrument of power for all the higher human life's activity.' The book was seen merely as a helper that can awaken feelings but it lacked the energy of the living word to awaken the human spirit.

\section{Theoretical model of learning in folk high school}


Grundtvig's conception postulates learning as a way to make man better, more conscious, and more refined in terms of his values. Therefore no emphasis was placed at people's schools on pure knowledge or on the development of skills, in the absence of awareness as to how to employ these to the benefit of oneself and one's surrounds; instead, people were encouraged to start with raising awareness of themselves (their potential) and of their place in the socium and only then to proceed to act "...so that their intelligence becomes keener, their judgement riper, their hearts nobler and more candid." (Rordam, 1965) This piece reflects on refining the culture of the mind, spirit, and will (a reflection of this may be found in the existential concept of P. Jarvis), openness of the mind, and on improving and securing higher values.

The people's school is seen as an institution of liberal (Bose, 1960; Kulich, 2002), free (Davis, 1971), popular (Rordam, 1965), and, of course, democratic (Bose, 1960) education. Undoubtedly the education of values was one of the most important elements in the movement of people's schools, with the idea 'to make people good and happy' in its centre (Campbell, 1928). In these institutions, the process of education was based on the following leading values: responsibility/joint responsibility, freedom, self-realization, co-operation, trust, flexibility and humanity.

In his theory, Grundtvig speaks of the full development of man as a process in which the spirit becomes fully aware of itself, its possibilities, national identity and consciousness. Man has to become aware of his potential as a human being, of what is naturally innate and of what is becoming for the human nature, first, and only then become aware of God and of his belonging to Christianity. (Campbell, 1928).

This and previous philosophical conceptions of Grundtvig's theory can be summarized into learning model showed below. (See Figure1)
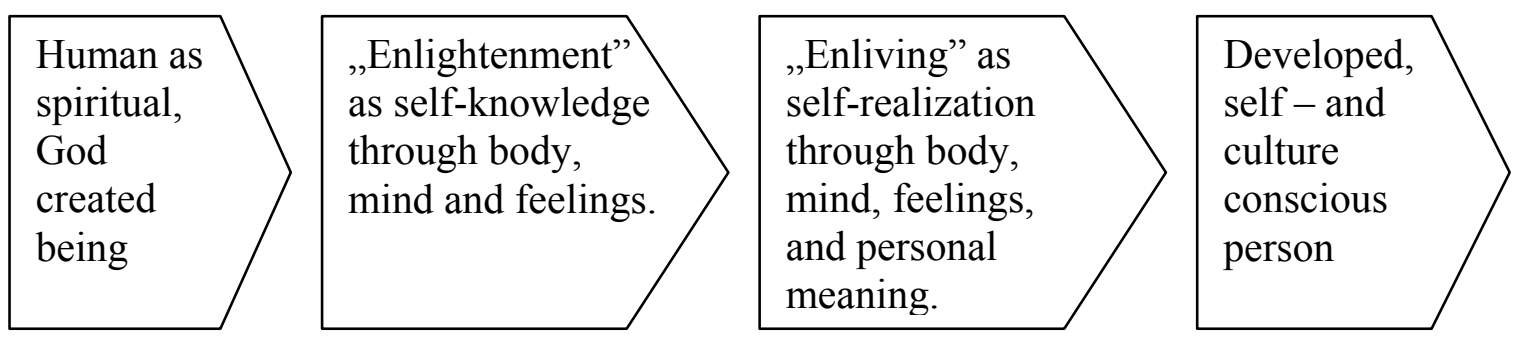

\section{Figure 1. Student's development process through learning in folk high school}

It is not the subject itself that plays an important role in the process of learning but the growth process which can be stimulated by it (Andresen, 1981). Memorising facts without giving a thought was opposed to the full human and spiritual development. Development of feelings, emotions, and will was a far more important task than memorising information. 'The whole person develops through activities that acknowledge both soul and body.' (Andresen, 1981). 
Davis (1928) believes that the pupil is in the centre of the process of education; from modern perspective, one may say that it is man that is in the centre - man as a value and the process of its formation, man's awareness and perfection of oneself. Thus the centre may come to encompass the pupil, the teacher, and the education-cultural environment (Cehlova, 2009) alike where the goal is left unchanged - man and his value as a spiritual being has the leading role, what is changed is only the placement of these three aspects. (See Figure 2)

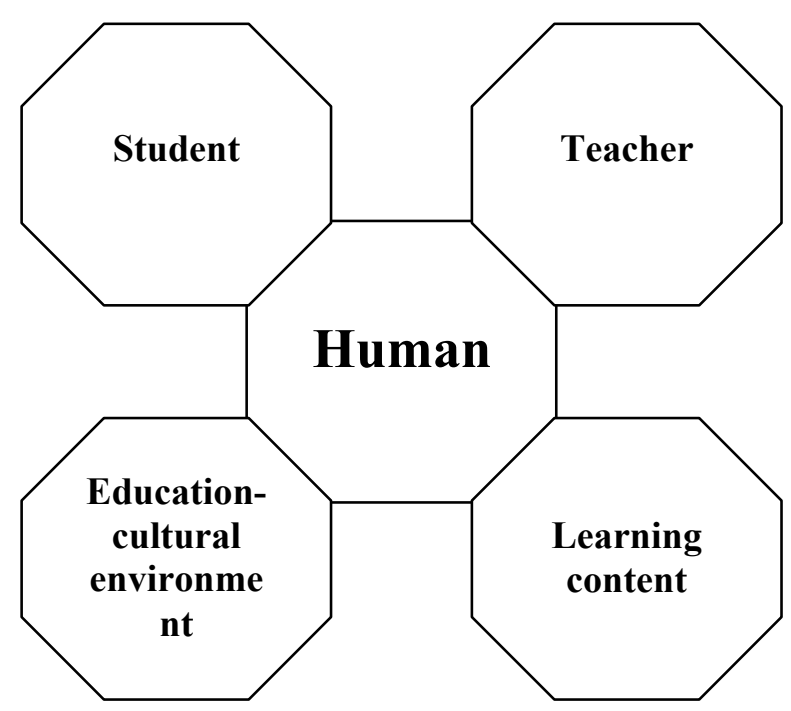

Figure 2. Process of education in folk high school

The main tool of the teacher was 'the living word' - the ability to inspire and to reveal contents through the live emotion and sensations within the pupil's soul (Rordam, 1965). The goal of the teacher is to promote interest about the subject of learning in the pupil's soul so that he could search for additional information after the classes and would not stop thinking about it, discussing it, and practicing it.

The processes of self-development (Maslow, Rogers, Davis) and socialisation (Vigotsky) may be viewed as the principal processes in these educational institutions. (Bogdzevich, 2009; Davies, 1931; Davis, 1971). Moreover, it was believed one should start specifically with individualisation, with becoming aware of one's own 'Self', and only then one should appear in the public and get involved in the processes of socialisation. Everything has to start with selfimprovement.

In describing the school curriculum, Grundtvig stressed that this was an opposition of the living school against the dead school (meaning by this grammar schools where the contents of books had to be learned by heart). Thus these institutions gave preference to subjects of culture and creativity rather than to exact subjects (although they never denied the possibility to study grammar, maths, and biology, if necessary). It is about measurement and harmony - which subject of the curriculum, and to what extent, will help man to awaken his spirit and to perceive the contents better; the formation of a curriculum may be started from here.

\section{Conclusions}


Learning process in folk high school can be characterized as interaction of self-realization and socialization process which result in perfected personality who has developped one's knowledge, skills, attitudes, competences and values.

In the center of learning process there is a person as the highest value. Therefore, in the center there can be a student, a teacher, an environment and contents - these elements only change their positions depending on the context but the aim of learning remains the same - a human as a value.

One of the main aspects in the folk high school education is the personal meaning that is similar to the idea of S.B. Merriam and a model about meaningmaking in 1996. Personal meaning is finding oneself, personal potential and talents, being conscious of the action place in one's consciousness and knowing how to realize it through the lens of the existing experience.

Folk high school education is value-oriented, it can be seen in the opinions of both Grundtvig and Kold - solidarity, respect, responsibility and love towards one's nation, people and God - are significant components that fill education, contents as well as relationship between a teacher and students.

Emotions and feelings are the main component that distinguish learning process in folk high school from other schools. The feeling of learning contents and surviving are the necessary basis in order to start studies and for the gained contents to stay in mind longer.

This work has been supported by the European Social Fund within the project «Support for Doctoral Studies at University of Latvia».

\section{Bibliography}

1. Andresen, Arne. (1981). The Danish Folk High School. Denmark: Hojskolernes Sekretariat.

2. Bertrup, Holger. (1936). The Folk-High Schools of Denmark. London: Oxford University Press.

3. Borish, Steven. (1991). The Land of the Living: The Danish Folk High Schools and Denmark's Non-Violent Path to Modernization. Nevada City, Calif.: Blue Dolphin.

4. Bose, Hiralal (1960). Danish Folk High Schools. Contemporary Review, 197 (1906: Jan./June). p.111-113

5. Campbell, Olive Dame. (1928). The Danish Folk School. New York, USA: The Macmillan Company.

6. Columbia Electronic Encyclopedia, 6th Edition; 10/1/2011, p 1-1, 1p

7. Čehlova, Zoja. Čehlovs, Mihails (2009). Skolotāju pedagogiskās kompetences teorētiskie pamati. Rīga: LU, lpp. 57-64

8. Davies, Noelle. (1931). Education For Life: A Danish Pioneer. London: Williams\&Norgate Ltd.

9. Davis, David.(1971). Model for a Humanistic Education: The Danish FolkHigh School. Columbus, Ohio: Charles E. Merrill Publishing Company.

10. Frommer, Arthur. (1986). Danish Folk Schools as Learning Experience. South Florida Sun-Sentinel [Fort Lauderdale, Fla] 30 Mar 1986: 4J.

11. Jarvis P. (2006). Towards a Comprehensive Theory of Human Learning. London: Routledge 
12. Korsgaard, Ove. (2000). Learning and the changing concept of enlightenment: Danish adult education over five centuries. International Review of Education. 46 (3/4): 305325.

13. Kulich, Jindra. (2002). Residential folk high schools in Eastern Europe and Baltic states. International Journal of Lifelong Education, Vol. 21, No.2 (March-April, 2002), 178-190+

14. Prial, Frank (1980). Danish Folk Schools: Live in and Learn. New York Times, 07 Sep 1980: A.24.

15. Scandinavian Seminar. Folk High School, What is it? http://www.scandinavianseminar.org/?id=95

16. The Association of Folk High Schools in Denmark http://www.ffd.dk/the-danish-folkhigh-school

17. The Law of Free Boarding Schools https://www.retsinformation.dk/Forms/R0710.aspx?id=25181

18. Rordam, Thomas. (1965). The Danish Folk High Schools. Denmark: Det Berlingske Bogtrykkeri.

19. Богдзевич, Арина. (2009). Тренер - группа - семинар: другой путь образования молодежи. Берлин: MitOst 21

\author{
Ludmila Babajeva University of Latvia \\ Jurmalas gatve 74/76, Riga, LV-1083, Latvia \\ E-mail: ludmila.babajeva@lu.lv \\ Phone: +37126791238
}

